\title{
Identification and Growth Characteristics of Alkalophilic Corynebacterium sp. Which Produces NAD(P)-Dependent Maltose Dehydrogenase and Glucose Dehydrogenase
}

\author{
Yoshinori KoBAYASHI* and Koki HoRIKOSHI \\ The Institute of Physical and Chemical Resarch, Wako, \\ Saitama 351, Japan \\ Received May 14, 1979
}

\begin{abstract}
An alkalophilic bacterium, strain No. 93-1, was isolated from soil. On the basis of the morphological and biochemical characteristics, this strain was identified to belong to the genus Corynebacterium. A crude extract of this strain showed NAD-dependent dehydrogenase activity on maltose (NAD-MalDH) and glucose (GlcDH). The ratio between these two dehydrogenase activities varied by cultural conditions. And NADP was also a suitable co-factor for dehydrogenase activity on maltose (NADP-MalDH). There were remarkable differences in an optimal temperature and $\mathrm{pH}$ stability among these three activities. According to these experimental results, we expected that, at least, three kinds of NAD (P)dependent dehydrogenase acted on maltose and glucose in the crude extract of this microorganism.
\end{abstract}

In the last decade, many alkalophilic microorganisms have been isolated and characteristics of extracellular enzymes produced by them have been reported.1 7) Also, physiological properties of these bacteria have been studied on amino acids transport, ${ }^{8 \text { ) }}$ protein synthesis, ${ }^{9)}$ and RNA synthesis. ${ }^{10)}$ But up to now, we have little knowledge about the reason why such high $\mathrm{pH}$ is necessary for the growth. In order to recognize this unique property of these bacteria, it is very important to get much information of intracellular enzymes in main metabolic pathways.

Many species of microorganisms which possessed the oxidation activity of glucose and other aldoses have been reported. And one of the responsible enzymes, glucose dehydrogenase was reviewed by Hauge and $\mathrm{Sa}-$ doff. ${ }^{11)}$ In Bacillaceae, NAD(P)-dependent glucose dehydrogenase(GlcDH; EC 1.1.1.47) has been studied in a view point of sporespecific enzyme. ${ }^{12 \sim 15)}$ As regards dehydro-

* On leave from Meito Sangyo Co., Ltd.

Abbreviations; NAD-MalDH, NAD-dependent maltose dehydrogenase; NADP-MaIDH, NADPdependent maltose dehydrogenase; GlcDH, NADdependent glucose dehydrogenase. genase which acts on disaccharides, we have few reports. Nishizuka and Hayaishi reported on a partially purified lactose dehydrogenase of Pseudomonas graveolens. $^{16)}$ Westermark and Eriksson described about cellobiose dehydrogenase of Polyporus versicolore and Sporotrichum pulverulentum. ${ }^{17}$ )

We isolated an alkalophilic Corynebacterium strain which produced three kinds of NAD(P)-dependent dehydrogenase which acted on carbohydrates. The first was a NADdependent dehydrogenase which exhibited high activity on maltose, "NAD-dependent maltose dehydrogenase(NAD-MalDH)." The second was "NADP-dependent maltose dehydrogenase (NADP-MalDH)." And the third was a NAD-dependent glucose dehydrogenase (GlcDH). This paper deals with the isolation and identification of this bacterium, some cultural conditions for enzyme production, and properties of the crude extract.

\section{MATERIALS AND METHODS}

Isolation of alkalophilic microorganisms. Alkalophilic microorganisms were isolated from soils in Japan ${ }^{2)}$ using Basal Medium II; $1 \%$ soluble starch, $0.5 \%$ peptone (polypepton), $0.5 \%$ yeast extract, $0.1 \%$ 
$\mathrm{K}_{2} \mathrm{HPO}_{4}, 0.02 \% \mathrm{MgSO}_{4} 7 \mathrm{H}_{2} \mathrm{O}, 2 \%$ agar, $1 \% \mathrm{Na}_{2} \mathrm{CO}_{3}$ (separately sterilized).

\section{Culture.}

(a) Screening. Ten ml of the liquid Basal Medium II in a test tube $(24 \times 200 \mathrm{~mm})$ was autoclaved at $120^{\circ} \mathrm{C}$ for $15 \mathrm{~min}$. One loopful of isolated microorganisms was inoculated and cultured aerobically for 2 days at $37^{\circ} \mathrm{C}$ on a reciprocal shaker.

(b) Examination of cultural conditions for enzyme production. Effect of initial $\mathrm{pH}$ of the medium, carbon sources and nitrogen sources were examined as follows; one loopful of the bacteria was inoculated to $50 \mathrm{ml}$ of the liquid medium in a $300-\mathrm{ml}$ Erlenmeyer fiask and cultured at $30^{\circ} \mathrm{C}$ for $24 \mathrm{hr}$ on a rotary shaker. Time course examination of enzyme production was examined in $600 \mathrm{ml}$ of the liquid medium in a $2-\mathrm{L}$ Erlenmeyer flask at $30^{\circ} \mathrm{C}$ on a rotary skaker.

Preparation of the crude extract. Cells were harvested and washed with $50 \mathrm{~mm}$ phosphate buffer, $\mathrm{pH}$ 7.5 , by centrifugation. The same buffer was added to cells and subjected to sonic oscillation at $20 \mathrm{KHz}$ for 3 to $5 \mathrm{~min}$ under cooling with ice. The supernatant fluid was obtained as the crude extract by centrifugation at $20,000 \times g$ for $20 \mathrm{~min}$.

Enzymes assay. NAD(P)-MalDH and GlcDH activities were assayed spectrophotometrically by the measurement of the increase of O.D. $340 \mathrm{~nm}$ with an Hitachi spectrophotometer model $200-10$ at $30^{\circ} \mathrm{C}$. Assay system contained $0.5 \mathrm{ml}$ of $100 \mathrm{~mm}$ glycine$\mathrm{NaOH}$ buffer, $\mathrm{pH} 10.0,0.1 \mathrm{ml}$ of $30 \mathrm{~mm} \mathrm{NAD}(\mathrm{P})$ solution, $0.1 \mathrm{ml}$ of $1 \mathrm{M}$ maltose or glucose solution, the crude extract and water to make up a total volume of $1 \mathrm{ml}$ in a cuvette with a light path of $1 \mathrm{~cm}$. One unit of these enzyme activities was defined as the amount of enzyme which catalyzed the reduction of $1 \mu \mathrm{mol}$ of NAD(P) per min at $30^{\circ} \mathrm{C}$. NAD $(\mathrm{P}) \mathrm{H}$ oxidase activities were also assayed spectrophtometrically by the measurement of the decrease of O.D. $340 \mathrm{~nm}$ with the same equipment at $30^{\circ} \mathrm{C}$. Assay mixture contained $0.5 \mathrm{ml}$ of $100 \mathrm{~mm}$ glycine- $\mathrm{NaOH}$ buffer, $\mathrm{pH} 10.0,0.1 \mathrm{ml}$ of $1 \mathrm{~mm} \mathrm{NAD(P)H}$ solution, the crude extract and water to make up a total volume of $1 \mathrm{ml}$ in a cuvette with a light path of $1 \mathrm{~cm}$.

Characterization and identification of the isolated bacteria. The isolated bacterium was characterized and identified according to Komagata's reports ${ }^{18 \sim 22)}$ and "Bergey's Manual of Determinative Bacteriology 8th ed."

Analytical methods. The bacterial growth was measured by the measurement of O.D.610 $\mathrm{nm}$ of the culture broth. Protein was determined from the absorbancies of O.D. at 260 and $280 \mathrm{~nm}$.
Chemicals. NAD, NADP, NADH and NADPH were purchased from Kyowa Hakko Kogyo Co. Ltd. Maltose was obtained from Nakarai Chemical Co., Ltd. Glucose was purchased from Wako Pure Chemical Co. Ltd.

\section{RESULTS}

Characterization and identification of the isolated microorganism.

About 150 soils were examined and approximately 600 colonies of bacteria, a few colonies of molds and actinomycetes were isolated. In these colonies, one yellow colored bacterium, strain No. 93-1, possessed strong activity of NAD-dependent dehydrogenase acted on maltose(NAD-MalDH). And also, this crude extract contained two or three times higher activity of NAD-dependent glucose dehydrogenase(GlcDH) than NADMalDH. The isolated alkalophilic microorganism, strain No. 93-1, was an aerobic gram positive, non-spore forming, motile, rodshaped bacterium and had peritrichous flagella. The morphological, cultural and biochemical characteristics are summarized in Table I. This bacterium showed good growth at the range of $\mathrm{pH} 7$ to 11 in Basal Medium II. In nutrient broth, the alkaline condition( $\mathrm{pH}$ 10) was more suitable for the growth than neutral condition( $\mathrm{pH} 7)$. On the basis of classification reported by Komagata et al., ${ }^{22)}$ this bacterium had both properties of genus Corynebacterium and Brevibacterium. In 'Bergey's Manual of Determinative Bacteriology 8th ed.," genus Brevibacterium is omitted. Therefore, this bacterium should belong to Corynebacterium. Although, there has been no report on a Corynebacterium sp. which is able to grow on such alkaline medium, the strain is designated as Corynebacterium sp. No. 93-1 in this study.

\section{Cultural conditions for enzyme production}

(a) Effect of initial pH on enzyme production. The effect of the initial $\mathrm{pH}$ of cultural medium on enzyme production was investigated using modified Basal Medium 
Table I. Morphological, Cultural and Biochemical

Characteristics of Strain No. 93-1

Morphological characteristics

Form

Size $(\mu)$

Motility

Flagellation

Spore formation

Gram stain

Acid fastness

Metachromatic granule

Type of cell division

Pleomorphism

Cultural characteristics

Nutrient broth

Nutrient agar slant

Nutrient giucose broth

Nutrient glucose agar slant

Basal Medium I*

Basal Medium I agar slant

Basal Medium II

Basal Medium II agar slant

Growth in $\mathrm{NaCl}$ $5 \%$ in Basal Medium I $7 \%$ $10 \%$

Liquefation of gelatine

Litmus milk

Biochemical characteristics

Obligate aerobic

Temperature for growth (Basal Medium II, pH 10 ); $20^{\circ} \mathrm{C}$ to $40^{\circ} \mathrm{C}$

pH for growth (Basal Medium II); 7 to 11

Main amino acid of cell wall; DL-DAP

GC content $(\%) ; 65.8$

Denitrification

Reduction of nitrate to nitrite

Methylred test

V.P test

Indole production

$\mathrm{H}_{2} \mathrm{~S}$ production

$\mathrm{O}-\mathrm{F}$ test

Urease test

Oxidase test

Catalase test

Hydrolysis of starch

Hydrolysis of casein

Hydrolysis of cellulose

Utilization of citric acid

Koser medium

Christensen medium

Utilization of ammonium salts

Water soluble pigment production

Acid production from sugars ( $\mathrm{pH} \mathrm{10)}$

Positive (without gas); glucose, fructose, xylose, sorbose, lactose, maltose, cellobiose, dextrin, starch.

Negative; arabinose, rhamnose, mannose, galactose, sucrose, trehalose, raffinose, inulin, glycerol, erythritol, adonitol, mannitol, dulcitol, sorbitol, inositol, arbutin, salicin, a-methyl glucoside.

* Basal Medium I; $1 \%$ glucose, $0.5 \%$ peptone (polypepton), $0.5 \%$ yeast extract, $0.1 \% \mathrm{~K}_{2} \mathrm{HPO}_{4}, 0.02 \%$ $\mathrm{MgSO}_{4} 7 \mathrm{H}_{2} \mathrm{O}, 1 \% \mathrm{Na}_{2} \mathrm{CO}_{3}$ (pH 10).

** N.G.; No growth.

*** N.T.; Not tested.
Rods

$\times 2,0-3.0$

Peritrichous flagella

Negative

Negative

Snapping

Not distinct

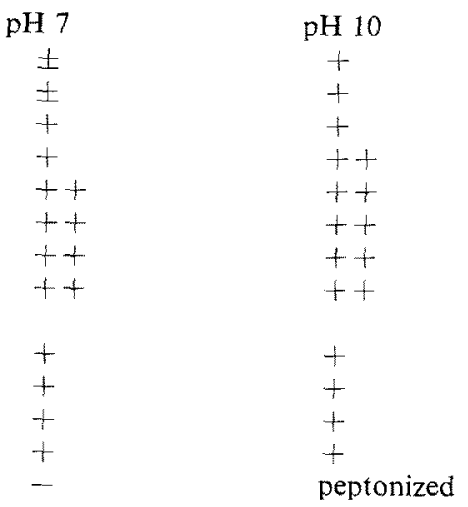

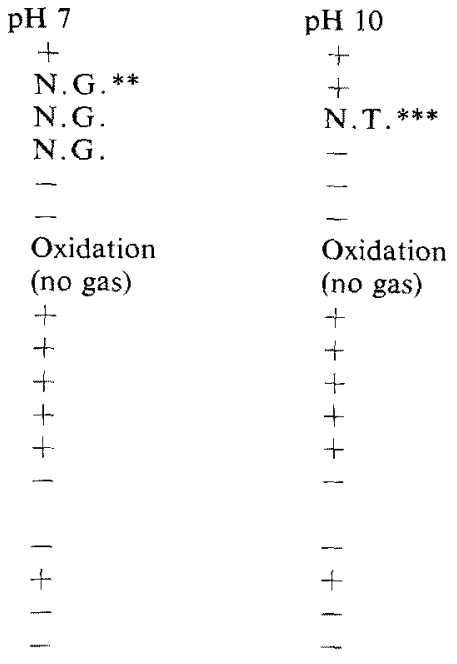


Table II. Effect of Initial pH on Enzyme Production

\begin{tabular}{lcccccc}
\hline $\begin{array}{c}\mathrm{Na}_{2} \mathrm{CO}_{3} \\
\text { conc. } \\
(\%)\end{array}$ & $\begin{array}{c}\text { Initial } \\
\mathrm{pH}\end{array}$ & $\begin{array}{c}\text { Final } \\
\mathrm{pH}\end{array}$ & $\begin{array}{c}\text { Bacterial } \\
\text { growth } \\
(\text { O.D. } 610)\end{array}$ & $\begin{array}{c}\text { Protein } \\
\text { (mg) }\end{array}$ & $\begin{array}{c}\text { NAD-MalDH } \\
\text { (total untis) }\end{array}$ & $\begin{array}{c}\text { GlcDH } \\
\text { (total units) }\end{array}$ \\
\hline 0 & 7.18 & 8.00 & 1.08 & 7.41 & 0.471 & 1.32 \\
0.05 & 8.00 & 8.43 & 1.20 & 8.23 & 0.508 & 1.49 \\
0.1 & 8.89 & 8.43 & 1.30 & 8.92 & 0.557 & 2.01 \\
0.2 & 9.60 & 8.90 & 1.32 & 9.06 & 0.726 & 2.98 \\
0.3 & 9.90 & 9.12 & 0.72 & 4.94 & 0.690 & 2.90 \\
0.5 & 10.20 & 9.55 & 0.58 & 3.98 & 0.448 & 1.82 \\
1.0 & 10.50 & 10.20 & 0.35 & 2.40 & 0.289 & 1.16 \\
\hline
\end{tabular}

Table III. Effect of Carbon Sources on Enyzme Production

\begin{tabular}{lccccc}
\hline $\begin{array}{c}\text { Carbon source } \\
(1 \%)\end{array}$ & Final pH & $\begin{array}{c}\text { Bacterial } \\
\text { growth } \\
(\text { O.D. } 610)\end{array}$ & $\begin{array}{c}\text { Protein } \\
(\mathrm{mg})\end{array}$ & $\begin{array}{c}\text { NAD-MalDH } \\
\text { (total units) }\end{array}$ & $\begin{array}{c}\text { GlcDH } \\
\text { (total units) }\end{array}$ \\
\hline D-Glucose & 8.20 & 1.82 & 9.80 & 0.049 & 0.067 \\
D-Mannose & 8.68 & 1.91 & 11.0 & 0.138 & 0.420 \\
D-Galactose & 8.85 & 1.92 & 10.3 & 0.672 & 2.40 \\
D-Fructose & 8.58 & 1.98 & 9.24 & 0.029 & 0.082 \\
D-Xylose & 8.82 & 1.97 & 11.7 & 0.696 & 2.52 \\
D-Ribose & 8.50 & 1.38 & 12.1 & 0.402 & 1.00 \\
D-Arabinose & 9.23 & 0.07 & 0.53 & 0 & 0 \\
Maltose & 8.73 & 1.58 & 10.7 & 0.540 & 2.82 \\
Lactose & 8.80 & 1.81 & 12.6 & 0.504 & 1.56 \\
Cellobiose & 8.53 & 2.48 & 13.4 & 0.116 & 0.696 \\
Melibiose & 8.72 & 2.42 & 11.0 & 0.570 & 2.23 \\
Sucrose & 8.38 & 2.44 & 8.93 & 0 & 0.050 \\
D-Mannitol & 8.48 & 2.00 & 9.45 & 0.064 & 0.192 \\
D-Xylitol & 9.10 & 0.83 & 3.15 & 0.348 & 1.44 \\
D-Sorbitol & 8.98 & 1.72 & 5.04 & 0.462 & 1.83 \\
D-Galactitol & 9.02 & 0.96 & 6.83 & 0.504 & 1.39 \\
Inositol & 8.78 & 1.55 & 4.20 & 0.346 & 1.50 \\
Soluble starch & 9.02 & 1.07 & 7.35 & 0.660 & 2.40 \\
Glycerol & 8.80 & 1.28 & 4.20 & 0.024 & 0.044 \\
None & 9.03 & 0.95 & 5.25 & 0.372 & 1.38 \\
\hline
\end{tabular}

II(yeast extract $0.1 \%$ ). The initial $\mathrm{pH}$ of the medium was adjusted by the addition of $\mathrm{Na}_{2} \mathrm{CO}_{3}$. Table II shows that the optimal concentration of $\mathrm{Na}_{2} \mathrm{CO}_{3}$ for enzyme production was $0.2 \%$. In the following experiments, this concentration was used.

(b) Effect of carbon sources on enzyme production. Various carbohydrates were tested as a carbon source in the modified Basal Medium II (soluble starch was omitted) for enzyme production. As shown in Table III, several kinds of carbohydrates were effective for the bacterial growth and enzyme production. Maltose and glucose were not essential for enzyme production. Therefore, it was clear that these enzymes were not an inducible type. We chose maltose as a carbon source and the optimal concentration of maltose for enzyme production was $1 \%$.

(c) Effect of nitrogen sources on enzyme production. The effect of various nitrogen sources was investigated in the modified Basal Medium II (without peptone (polypepton), containing $1 \%$ maltose). Table IV shows that organic nitrogen sources such as soya-bean casein etc. were essential for the growth. But inorganic nitrogen sources such as $\mathrm{NH}_{4} \mathrm{NO}_{3}, \mathrm{NH}_{4} \mathrm{Cl}, \mathrm{NaNO}_{3}, \mathrm{KNO}_{3}$, $\mathrm{NH}_{4} \mathrm{H}_{2} \mathrm{PO}_{4}$ and $\left(\mathrm{NH}_{4}\right)_{2} \mathrm{HPO}_{4}$ were not effective. The optimal concentraion of soya-bean 
Table IV. Effect of Nitrogen Sources on Enzyme Production

\begin{tabular}{lccccc}
\hline $\begin{array}{c}\text { Nitrogen } \\
\text { source } \\
(0.5 \%)\end{array}$ & Final pH & $\begin{array}{c}\text { Bacterial } \\
\text { growth } \\
(\text { O.D. } 610)\end{array}$ & $\begin{array}{c}\text { Protein } \\
(\mathrm{mg})\end{array}$ & $\begin{array}{c}\text { NAD-MalDH } \\
\text { (total units) }\end{array}$ & $\begin{array}{c}\text { GlcDH } \\
\text { (total units) }\end{array}$ \\
\hline Peptone (polypepton) & 8.90 & 0.98 & 4.40 & 0.419 & 1.35 \\
Soya-bean casein & 8.19 & 10.6 & 45.5 & 3.27 & 9.68 \\
Yeast extract & 8.90 & 0.97 & 3.85 & 0.183 & 0.637 \\
Beef extract & 8.91 & 0.95 & 3.05 & 0.194 & 0.766 \\
Corn steep liqure & 8.70 & 3.41 & 21.5 & 1.29 & 3.01 \\
Casamino acids & 9.02 & 0.85 & 3.63 & 0.254 & 0.790 \\
Urea & 9.71 & 0.21 & 0.225 & 0 & 0 \\
Ammonium sulfate & 8.88 & 0.48 & 0.310 & 0.011 & 0 \\
\hline
\end{tabular}

casein for enzyme production was $1 \%$. Therefore, for enzyme production, following composition of medium was used; $1 \%$ maltose, $1 \%$ soya-bean casein, $0.1 \%$ yeast extract, $0.1 \% \mathrm{~K}_{2} \mathrm{HPO}_{4}, 0.02 \% \mathrm{MgSO}_{4} 7 \mathrm{H}_{2} \mathrm{O}$ and $0.2 \%$ $\mathrm{Na}_{2} \mathrm{CO}_{3}$.

(d) Time course examination of enzyme production. Time course of the bacterial growth and enzyme production were investigated. As shown in Fig. 1, after the decrease of $\mathrm{pH}$, rapid bacterial growth appeared and the enzyme activities reached maiximum at $24 \mathrm{hr}$-culture.

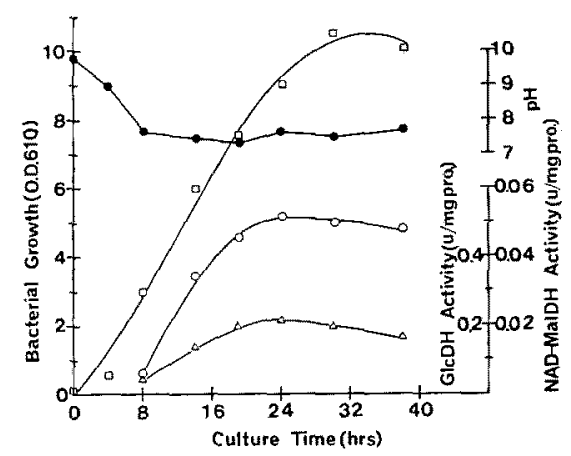

FIG. 1. Time Course of Bacterial Growth and Enzyme Production.

Experimental conditions are described in Materials AND METHODs. $\square$, bactral growth; $\bullet$, pH; O, NADMalDH activity; $\triangle$, GlcDH activity.

\section{Properties of the curde extract}

(a) Co-factor requirement. When maltose and glucose were used as the substrate, the requirement of NAD and NADP was examined. As shown in Fig. 2, NADP was slightly effective than NAD on dehydrogen-

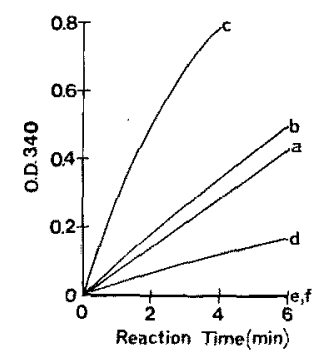

FIG. 2. Co-factor Requirement.

Examination was carried out in accordance with the assay method described in MATERIALS AND Methods. $a$, maltose +NAD; b, maltose +NADP; $c$, glucose + NAD; d, glucose+NADP; e, NAD; f, NADP.

ation of maltose and NAD was significantly effective than NADP on dehydrogenation of glucose. And no NAD $(\mathrm{P}) \mathrm{H}$ oxidase activity was detected during the assay process.

(b) Effect of $p H$. Using NAD and NADP as a co-factor, optimal $\mathrm{pH}$ of dehydrogenase activity on maltose was examined. Fig. 3 shows that optimal $\mathrm{pH}$ of NAD-MalDH

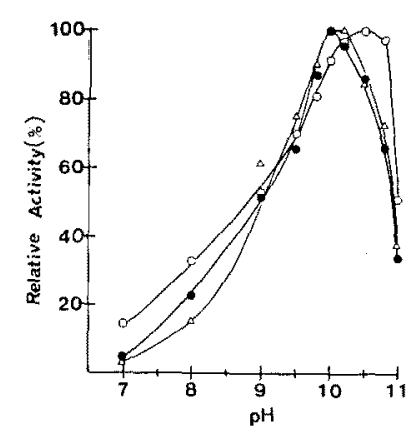

Fig. 3. Optimal pH of Enzyme Activity. pH 7-8, phosphate buffer; pH 9-11, glycine- $\mathrm{NaOH}$ buffer. $O$, NAD-MalDH; •, NADP-MalDH; $\triangle$, GlcDH. 


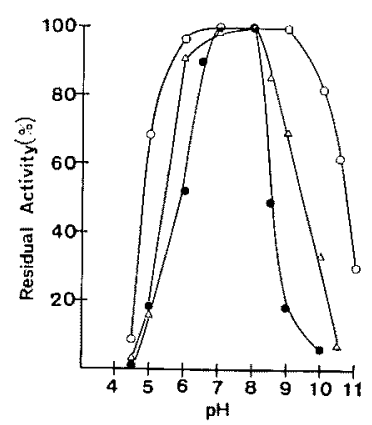

FIG. 4. pH Stability of Enzyme Activity.

After the treatment of the crude extract in eah buffer for $30 \mathrm{~min}$ at $30^{\circ} \mathrm{C}$, the residual activity was measured. pH 4.5 5, succinate buffer; pH 6 8.5, phosphate buffer; $\mathrm{pH} 9 \sim 11$, glycine-NaOH buffer. $\mathrm{O}$, NAD$\mathrm{MalDH} ; \bullet$, NADP-MalDH; $\triangle, \mathrm{GlcDH}$,

was around 10.5 and that of NADP-MalDH was around 10.0. As shown in Fig. 2, NADPdependent glucose dehydrogenase activity was very low. Therefore, only optimal pH of NAD-dependent glucose dehydrogenase activity was investigated. Fig. 3 shows that optimal $\mathrm{pH}$ of $\mathrm{GlcDH}$ was around 10.0 to 10.2. Fig. 4 shows $\mathrm{pH}$ stability of these three dehydrogenase activities. NAD-MalDH was stable at the $\mathrm{pH}$ range of 6.5 to 9.0 . NADP-MalDH was stable at the $\mathrm{pH}$ range of 7.0 to 8.0 . The stable $\mathrm{pH}$ range of GlcDH was 6.0 to 8.0 .

(c) Effect of temperature. Fig. 5 shows the optimal temperature of these activities. Optimal temperature of NAD-MalDH was $50^{\circ} \mathrm{C}$ and that of NADP-MalDH was 40 to $45^{\circ} \mathrm{C}$. As regards $\mathrm{GlcDH}, 35^{\circ} \mathrm{C}$ was optimal. Thermal stability was shown in

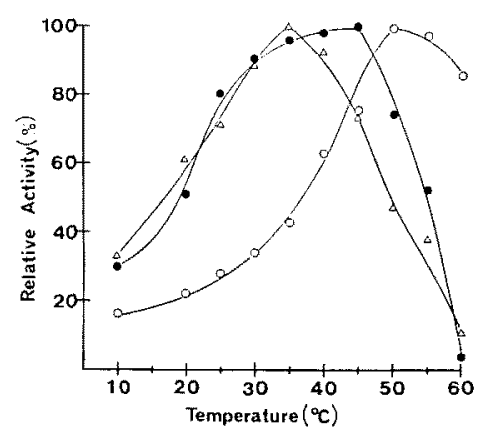

FIG. 5. Optimal Temperature of Enzyme Activity. O, NAD-MalDH; •, NADP-MalDH; $\triangle$, GIcDH.

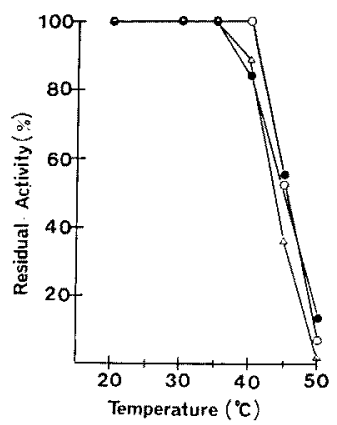

FIG. 6. Thermal Stability of Enzyme Activity.

After the treatment of the crude extract with each temperature for $10 \mathrm{~min}$ in $50 \mathrm{~mm}$ phosphate buffer pH 7.0, the residual activity was measured. $O$, NADMalDH; , NADP-MalDH; $\triangle$, GlcDH.

Fig. 6. NAD-MalDH was stable up to $40^{\circ} \mathrm{C}$. NADP-MalDH and GlcDH were stable up to $35^{\circ} \mathrm{C}$ and lost these activities in the similar degree at the above temperature.

\section{DISCUSSION}

Glucose dehydrogenase has been known in various microorganisms and reviewed by Hauge and Sadoff. ${ }^{11}$. The enzyme was classified into two types. One was a particlebound type and existed mainly in Pseudomonas and Acetobacter species. The enzyme in Pseudomonas sp. could use oxygen, 2,6dichlorophenolindophenol and phenazine methosulfate as an electron acceptor, but could not use NAD and NADP. This enzyme acted on several kinds of aldoses, but it showed low activity on maltose and lactose. However, when it was solubilized, it acted on these disaccharides in the same degree on glucose. The other was a soluble type and found in Bacillaceae. This soluble type glucose dehygrogenase has been studied in a view point of spore-specific enzyme. This enzyme could use NAD and NADP as electron acceptors.

In regards to microorganisms which could oxidize disaccharides, e.g., lactose, maltose and cellobiose to corresponding aldobionic acids, Pseudomonas sp. has been well known. Bentyly et al. reported about the oxidation of monosaccharides and disaccharides to cor- 
responding aldonic acids and aldobionic acids by the extract of Pseudomonas sp. ${ }^{23)} \mathrm{Ni}$ shizuka and Hayaishi reported on the partially purified lactose dehydrogenase of Pseudomonas graveolens. ${ }^{16\}}$ This enzyme could use artificial electron acceptor such as 2,6-dichlorophenolindophenol, methylen blue and ferricyanide, but could not use oxygen, pyridine nucleotides and heart muscle cytochrome C. In spite of their attempt of further purification, the enzyme was not purified completely. Westermark and Eriksson reported on cellobiose:quinone oxidoreductase (cellobiose dehydrogenase) of white-rot fungi, Polyporus versicolore and Sporotrichum pulverulentum, in wood degradation. This enzyme showed high specificity on cellobiose and did not act on maltose and glucose.

We searched for NAD-dependent dehydrogenase which showed high activity on maltose in alkalophilic microorganisms. An isolated strain was identified as Corynebacterium sp. As shown in Table II, this strain showed good growth at the range of $\mathrm{pH} 7$ to 10 and recognized as facultative alkalophilic bacteria. The cell-free extract of this strain showed high NAD-dependent dehydrogenase activity on maltose and glucose. One of the main point of the examination of cultural conditions for enzyme production was to make clear whether these two activities were separate entities or not. In the results shown in Tables II to IV, the ratio of the activity of GIcDH/NAD-MalDH varied from about 2.3 to 6 . In the examination of properties of the crude extract, we found that NADP was also a suitable co-factor for dehydrogenase activity on maltose. Therefore, we compared the properties of dehydrogenases. As shown in Figs. 3 and 6, there were slight differences in optimal $\mathrm{pH}$ and thermal stability among these three activities. In $\mathrm{pH}$ stability and optimal temperature, there were remarkable differences. In addition, these three activities were located in soluble fraction obtained by the centrifugation at $100,000 \times g$. On the basis of these experimental results, we expected that, at least, three kinds of NAD or NADPdependent dehydrogenase acted on maltose and glucose existed in the crude extract and these NAD-MalDH and NADP-MalDH were new type enzymes. Therefore, works on the purification of these enzymes are in progress.

\section{REFERENCES}

1) K. Horikoshi, Agric. Biol. Chem., 35, 1407 (1971).

2) K. Horikoshi, ibid., 35, 1783 (1971).

3) K. Horikoshi, ibid., 36, 285 (1972).

4) Y. Kurono and K. Horikoshi, ibid., 37, 2565 (1973).

5) K. Horikoshi and Y. Atsukawa, Biochem. Biophys. Acta., 384, 477 (1975).

6) N. Nakamura and K. Horikoshi, Agric. Biol. Chem. 40, 753 (1976).

7) M. Kitada and K. Horikoshi, J. Ferment. Technol., 54, 383 (1976).

8) M. Kitada and K. Horikoshi, J. Bacteriol, 131, 784 (1977).

9) Y. Ikura and K. Horikoshi, Agric. Biol. Chem., 42, 753 (1978).

10) T. Kudo and K. Horikoshi, "Spores VII," ed. by Chambliss and Vary, American Society for Microbiology, Washington D.C. 1978 , p. 220.

11) J. G. Hauge and H. L. Sadoff, "Methods in Enzymology," vol. 9, ed. by S.P. Colowick and N.O. Kaplan, Academic Press Inc., New York, 1966, p. 92.

12) R. Gavard and C. Comgre, Comptes rendus, 349, 2243 (1959).

13) C. Prasad, M. Diesterhaft and E. Freese, $J$. Bacteiol., 110, 321 (1972).

14) Y. Hachisuka and K. Tochikubo, ibid., 107, 442 (1971).

15) Y. Fujita, R. Ramaly and E. Freese, ibid., 132, 282 (1977).

16) Y. Nishizuka and O. Hayaishi, J. Biol. Chem., 237, 2721 (1962).

17) U. Westermark and K. -E. Eriksson, Acta Chem. Scand. B, 28, 215 (1974).

18) K. Komagata, K. Yamada and H. Ogawa, $J$. Gen. Appl. Microbiol., 15, 243 (1969).

19) K. Yamada and K. Komagata, ibid., 16, 103 (1969).

20) K. Yamada and K. Komagata, ibid., 16, 215 (1969).

21) K. Yamada and K. Komagata, ibid., 18, 399 (1972).

22) K. Yamada and K. Komagata, ibid., 18, 417 (1972).

23) R. Bently and L. Slechta, J. Bacteriol, 79, 346 (1960). 